\title{
A Technological Solution for an Everywhere Energy Supply With \\ Sun, Hydrogen, and Fuel Cells
}

F. Orecchini

\section{A. Santiangeli}

\section{A. Dell'Era}

\author{
GEA-Energy and Environment Group, \\ CIRPS-Interuniversity Research Centre \\ for Sustainable Development, \\ University of Rome "La Sapienza," \\ Piazza del Colosseo, 9, Rome, Italy
}

The hydrogen economy is still at the beginning, but society, innovation, and the market push inexorably toward hydrogen, inspiring the idea to build an energy-integrated system that can satisfy, in an independent way, the energy needs of small-sized consumers. The technologies used for the system design are already available in the market and, at least for the standard solutions, sufficiently mature. The innovation consists of an integration, optimization, and industrialization of this modular system, which is an electric zeroemissions generator, giving $3.5 \mathrm{~kW}_{\mathrm{p}}$ as an output power. This is the only system able to produce its own fuel, guaranteeing renewable and clean energy, available where and when you want. This system is constituted by a polymer membrane electrolyzer, a metal hydrides tank (which absorbs and desorbs hydrogen), and a polymer fuel cell (PEM). The system modularity can also satisfy higher energy requirements, and the low-pressure hydrogen storage system through metal hydrides guarantees the system safety.

[DOI: $10.1115 / 1.2134740$ ]

\section{Introduction}

Hydrogen is the fuel for the future, and the future is today. The hydrogen economy is still at the beginning, but society, innovation, and the market push inexorably toward hydrogen, inspiring the idea to build an energy integrated system that can satisfy, in an independent way, the energy needs of small-sized consumers.

According to the "Closed Cycles Philosophy" $[1,2]$ of the GEA research group (Energy and Environment Group of CIRPSInteruniversity Center of Research For Sustainable Development, University of Rome "La Sapienza"), this integrated system realizes a closed-cycle that is ecologically neuter and sustainable because, by using renewable resources, it generates power without producing refusals (Fig. 1).

The technologies used for the system design are already available in the market and, at least for the standard solutions, sufficiently mature. The innovation consists of an integration, optimization, and industrialization of this modular system, which is an electric zero-emissions generator, giving $3.5 \mathrm{~kW}_{\mathrm{p}}$ as an output power. This is the only system able to produce its own fuel, guaranteeing renewable and clean energy, available where and when you want.

The peculiar characteristic is the possibility of producing a fuel (hydrogen) for use in the case of a low-power requirement and to store it in special tanks. In this way, thanks to the energy reservoir, the system can fulfill the power demand as soon as it get increased.

This is constituted by several components: a polymer membrane electrolyzer powered by renewable energy sources, which is able to split the water into its two constituent elements: $\mathrm{H}_{2}$ and $\mathrm{O}_{2}$; a metal hydrides tank that absorbs and desorbs hydrogen or, as an alternative, a low-pressure tank ( $\sim 10$ bar of pressure); a polymer fuel cell (PEM) that, recombining $\mathrm{H}_{2}$ and $\mathrm{O}_{2}$, generates electricity and heat.

The hydrogen production via electrolysis from renewable energy sources (sun, wind, biomass, and water) enables one to re-

Manuscript received July 20, 2005; final manuscript received August 1, 2005. Review conducted by Nigel M. Sammes. Paper presented at the 3rd International Fuel Cell Science Engineering and Technology Conference (FUELCELL2005), May 23, 2005-May 25, 2005, Ypsilanti, MI, USA move the accumulator packages and the SOC (state-of-charge) logic from the energy storage system while directly connected to the electrolyzer.

Moreover, the system modularity can also cover greater energy requirements, and the low-pressure hydrogen storage system with metal hydrides guarantees the system safety. This integrated system (see Fig. 2), able to produce and use the fuel of the future, will be perfectly inserted in the nascent "environment market." It will use high-tech products and aims at preserving the environment. It can be used anytime a clean energy (zero emission of pollutants) autonomous production is needed, such as, for example, all end users who consider environmental concerns as a priority and/or a highly added value.

The main interest domains for the integrated system are as follows:

Guarded areas: small users in natural parks (for bearing and transmission data stations, radio-television relays, telephonic appliances, bird-watching stations, water pumping plants, irrigation and lighting automatic systems, cathode protection of pipes, and/or for small bungalows)

Pleasure craft: auxiliary generators or portable generators while using a storage sub-system including only metal hydrides $+\mathrm{FC}$

Emergency units: medical on-field applications

Local boards: small municipality holding demonstrative plants that utilize energetic clean technologies. A great number of municipalities are interested in a clean and distributed production of electricity. The renewable resources can satisfy a relevant part of the energetic requirements (schools, public offices, streets, gardens and monument lighting, road signs)

Prestigious residences and rural houses: direct electric supply

Fairs: stands powered by clean energy

Tourist areas: bungalows in tourist villages, bathhouses, farms, and mountain areas. In this way the possibility of exclusively using clean, off-grid, and stable power for the "environmentally sensible" people can be achieved.

\section{Integrated System}

The sun is one of the most significant renewable energy sources. The global solar radiation in Italy during the day has been calculated as well as the average value for each month of the year, 


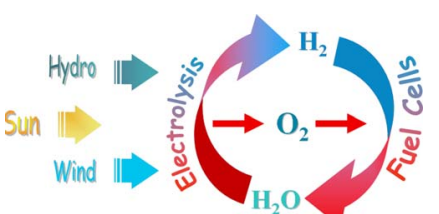

Fig. 1 Closed cycles

in order to estimate the size of the proposed system. During the day it utilizes the solar energy directly, satisfying the energy requirement of the users, but in this way the energy surplus is not used.

The following relationship provides the incident angle between the photovoltaic panel surface and the sun's rays.

The declination is

$$
\delta=23.45 \sin \left(360 \frac{284+m}{365}\right)
$$

where $m$ is the number of the days. The hour angle is

$$
\omega=n-12 \times 15 \times \frac{2 \pi}{360}
$$

where $n$ is the hours number.

The horizon solar height is

$$
\alpha=\arcsin \{[\cos (\phi) \cos (\delta) \cos (\omega)]+\operatorname{sen}(\phi) \operatorname{sen}(\delta)\}
$$

and the azimuth

$$
\gamma=\arcsin \left(\frac{\cos (\delta) \sin (\omega)}{\sin \left(\frac{\pi}{2}-\alpha\right)}\right)
$$

Therefore, the incidence angle $\theta$ of the beams on a horizontal surface is

$$
\begin{aligned}
\cos (\theta)= & \cos (\phi) \cos (\beta) \cos (\delta) \cos (\omega) \\
& +\sin (\phi) \sin (\beta) \cos (\gamma) \cos (\delta) \cos (\omega) \\
& +\sin (\beta) \sin (\gamma) \cos (\delta) \sin (\omega)+\sin (\phi) \cos (\beta) \sin (\delta) \\
& -\cos (\phi) \sin (\beta) \cos (\gamma) \sin (\delta)
\end{aligned}
$$

In order to calculate all three solar components, the solar constant $\mathrm{G}$ (which is $\sim 1353 \mathrm{~W} / \mathrm{m}^{2}$ ) is needed. Taking into account the variation of the distance from the Earth to the Sun in several days of the year and the incidence angle $\theta$ of the beams on a horizontal surface, the intensity of the extra-atmospheric radiation upon a horizontal surface in every moment of the day has been estimated,

$$
I_{0}=\left[1+0.033 \cos \left(\frac{360}{365} m\right)\right] I_{s c} \cos (\theta)\left[\mathrm{W} \mathrm{m}^{-2}\right]
$$

Integrating the values of $I_{0}$ between sunrise and sunset, the daily extra-atmospheric radiation upon a horizontal surface has been obtained,

$$
H_{0}=\int_{-\omega s}^{\omega s} I_{0} d\left(\frac{24}{2 \pi} \omega\right)\left[\mathrm{W} \mathrm{h} \mathrm{m}^{-2} \mathrm{day}^{-1}\right]
$$

where $\omega$ is the hour angle, $-\omega_{s}$ is the sunrise hour angle and $\omega_{s}$ is the sunset hour angle.

From Lyu and Jordan equations [3], the daily diffuse solar radiation $H_{d}$ and daily total solar radiation $H$ ratio can be measured, both referred to a ground horizontal surface,

$$
\frac{H_{d}}{H}=1.0045+0.04349 K_{t}-3.5227 K_{t}^{2}+2.6313 K_{t}^{3}
$$

This ratio is a function of the daily cloudiness index $K_{t}$; that is

$$
K_{t}=\frac{H}{H_{0}}
$$

This parameter can assume values between 0 and 0.75 . The diffuse component increases with the cloudiness index [4-6]. Afterward using the following equations:

$$
\begin{gathered}
\frac{I_{d h}}{H_{d}}=\frac{\pi}{24} \frac{\cos \omega-\cos \varpi_{s}}{\sin \varpi_{s}-\frac{\pi}{180} \cos \varpi_{s}} \\
\frac{I_{h}}{H}=\frac{\pi}{24}(a+b \cos \omega) \frac{\cos \omega-\cos \varpi_{s}}{\sin \varpi_{s}-\frac{\pi}{180} \cos \varpi_{s}}
\end{gathered}
$$

where

$$
\begin{aligned}
& a=0.409+0.5016 \cdot \sin \left(\omega_{s}-60\right) \\
& b=0.6609-0.4767 \cdot \sin \left(\omega_{s}-60\right)
\end{aligned}
$$

All the three radiation components have been evaluated over the whole day as a function of the incidence angle $\theta$ of the beams upon a horizontal surface,

$$
\begin{gathered}
I_{k}(\theta)=\left(\frac{I_{k}}{H}-\frac{I_{d h}}{H_{d}} \frac{H_{d}}{H}\right) H_{0} K_{t} \frac{\cos \theta}{\sin \alpha}\left[\mathrm{W} \mathrm{m}^{-2}\right] \\
I_{d h}(\theta)=\frac{I_{d h}}{H_{d}} \frac{H_{d}}{H} H_{0} K_{t} F V_{\text {sky }}\left[\mathrm{W} \mathrm{m}^{-2}\right]
\end{gathered}
$$

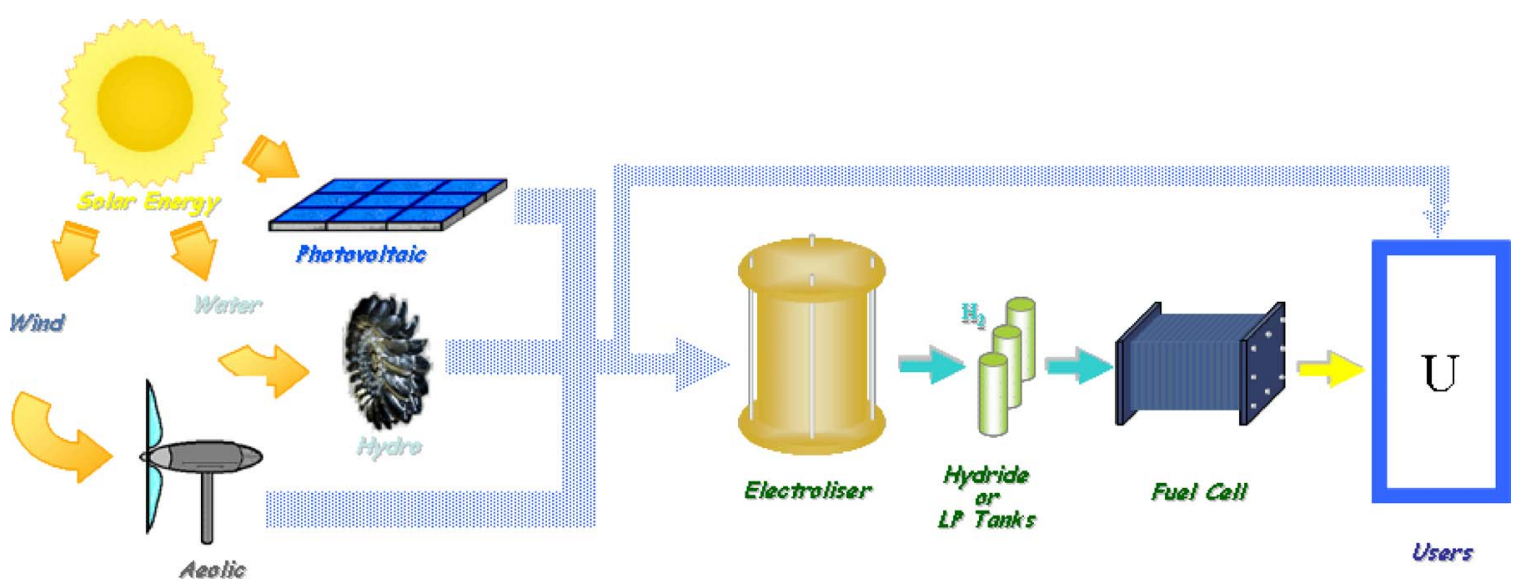

Fig. 2 Integrated system 
Table 1 Solar parameter

\begin{tabular}{|l|c|c|}
\hline Direct solar radiation & $H_{b}$ & $\mathrm{~J} / \mathrm{m}^{2}$ \\
\hline Diffuse solar rad. & $H_{d}$ & $\mathrm{~J} / \mathrm{m}^{2}$ \\
\hline Global solar rad. & $H=H_{b}+H_{d}$ & $\mathrm{~J} / \mathrm{m}^{2}$ \\
\hline Horizontal Global solar rad. & $H_{h}$ & $\mathrm{~J} / \mathrm{m}^{2}$ \\
\hline Hor. extratmospheric solar rad. & $H_{h o}$ & $\mathrm{~J} / \mathrm{m}^{2}$ \\
\hline Solar Constant & $G_{o}$ & $1353 \mathrm{~W} / \mathrm{m}^{2}$ \\
\hline Declination & $\delta$ & $\mathrm{rad}$ \\
\hline Azimut & $\gamma$ & $\mathrm{rad}$ \\
\hline Inclination & $\beta$ & $\mathrm{rad}$ \\
\hline Horizon solar height & $\alpha$ & $\mathrm{rad}$ \\
\hline Hour angle $15 \%$ hour & $\omega$ & $\mathrm{rad}$ \\
\hline
\end{tabular}

$$
I_{a h}(\theta)=\frac{I_{k}}{H} \rho H_{0} K_{t} F V_{\text {obstructions }}\left[\mathrm{W} \mathrm{m}^{-2}\right]
$$

$K_{t}$ and then all the three components of the global radiation for the selected geographic area ( $\sim 42$ deg of latitude) have been calculated by integrating the sum of the direct, diffuse, and reflected radiation and comparing the result obtained to the monthly average value of the energy measured for Italy (see Tables 1-8). Then the graphs of the global radiation during the day for all months of the year are reported, assessing a day in the middle of every month and considering the radiation during this day as a monthly average value of the global radiation. Figures 3-6 depict the radiation, in kilowatts per meters squared, as a function of the daily hours for all the seasons of the year.

These results have been obtained considering a photovoltaic surface of $1 \mathrm{~m}^{2}$ and calculating the correspondent tilt to the maximum global radiation. The azimuth angle to obtain the best radiation value must always be zero.

The next graph (Fig. 7) shows the tilt value calculated for every

Table 2 Available energy [kWh]

\begin{tabular}{|l|c|c|c|}
\hline & \multicolumn{3}{|c|}{ Available Energy [kWh] } \\
\hline PV surface & $20 \mathrm{~m}^{2}$ & $30 \mathrm{~m}^{2}$ & $40 \mathrm{~m}^{2}$ \\
\hline January & 9,7 & 14,5 & 19,4 \\
\hline February & 11,6 & 17,4 & 23,2 \\
\hline March & 14,1 & 21,2 & 28,3 \\
\hline April & 16,8 & 25,2 & 33,6 \\
\hline May & 19,8 & 29,7 & 39,6 \\
\hline June & 21,4 & 32,1 & 42,8 \\
\hline July & 24,3 & 36,4 & 48,6 \\
\hline August & 20,2 & 30,3 & 40,4 \\
\hline September & 17,3 & 26 & 34,7 \\
\hline October & 15,1 & 22,6 & 30,1 \\
\hline November & 10,9 & 16,4 & 21,8 \\
\hline December & 8,7 & 13,1 & 17,5 \\
\hline
\end{tabular}

Table 3 Electrolyzer characteristic

\begin{tabular}{|l|c|c|}
\hline Parameter & Conventional & Advanced \\
\hline Current Density $\mathrm{J}_{\mathrm{t}}\left[\mathrm{A} / \mathrm{cm}^{2}\right]$ & 0,2 & 1,3 \\
\hline Ohmic Overpotential $[\mathrm{V}]$ & 0,2 & 0,14 \\
\hline Electrolysis Overpotential [V] & 0,5 & 0,38 \\
\hline Cells Voltage [V] & $2-1,8$ & 1,6 \\
\hline Voltage Efficiency & $0,747-0,83$ & 0,9 \\
\hline Faradic Efficiency & 0,985 & 0,99 \\
\hline Global Efficiency & $0,62-0,70$ & 0,8 \\
\hline $\begin{array}{l}\text { Specific Energy Consumption } \\
{\left[\mathrm{kWh} / \mathrm{Nm}^{3}\right]}\end{array}$ & $4,83-4,29$ & 3,85 \\
\hline
\end{tabular}

month of the year. In order to have the maximum solar radiation, the surface of photovoltaic modules has to rotate accordingly during the year.

A surface of $\sim 40 \mathrm{~m}^{2}$ featuring a $15 \%$ photovoltaic efficiency gives the results depicted in the graphs of Figs. 8-11, where the power generated during the day has been estimated. The curved shapes are the same as those of the previous graphs, but the values are obviously increased. Integrating the curve's subtended area, the energy, in kilowatt hours, units available to the user has been obtained.

Table 2 reports the values of the energy available for every month of the year and for different photovoltaic surfaces installed.

The average energy needs of an Italian family for one day are $\sim 9 \mathrm{kWh}$, and the family is supposed to use $55 \%$ of this energy during the daylight hours, directly from the photovoltaic system. The remaining energy to be supplied is $4 \mathrm{kWh}$ during the evening and night. Therefore, this amount of energy has to be produced and stored during the day, exploiting the sunshine.

How this can be done? It can be done by producing hydrogen from water and accumulating it either in a normal tank or in a special one containing a particular material able to adsorb and desorb hydrogen. To produce hydrogen, an electrolyzer that splits distilled water into hydrogen and oxygen has been taken into account, as shown in Fig. 12.

Table 4 Available energy to produce hydrogen [kWh]

\begin{tabular}{|l|c|c|c|}
\hline & \multicolumn{3}{|c|}{ Available Energy to produce hydrogen $[\mathrm{kWh}]$} \\
\hline PV surface & $20 \mathrm{~m}^{2}$ & $30 \mathrm{~m}^{2}$ & $40 \mathrm{~m}^{2}$ \\
\hline January & 4,7 & 9,5 & 14,4 \\
\hline February & 6,6 & 12,4 & 18,2 \\
\hline March & 9,1 & 16,2 & 23,3 \\
\hline April & 11,8 & 20,2 & 28,6 \\
\hline May & 14,8 & 24,7 & 34,6 \\
\hline June & 16,4 & 27,1 & 37,8 \\
\hline July & 19,3 & 31,4 & 43,6 \\
\hline August & 15,2 & 25,3 & 35,4 \\
\hline September & 12,3 & 21 & 29,7 \\
\hline October & 10,1 & 17,6 & 25,1 \\
\hline November & 5,9 & 11,4 & 16,8 \\
\hline December & 3,7 & 8,1 & 12,5 \\
\hline
\end{tabular}


Table 5 Hydrogen produced $\left[\mathrm{Nm}^{3}\right]$

\begin{tabular}{|l|c|c|c|}
\hline & \multicolumn{3}{|c|}{ Hydrogen produced $\left[\mathrm{Nm}^{3}\right]$} \\
\hline PV surface & $20 \mathrm{~m}^{2}$ & $30 \mathrm{~m}^{2}$ & $40 \mathrm{~m}^{2}$ \\
\hline January & 1,2 & 2,5 & 3,7 \\
\hline February & 1,7 & 3,2 & 4,7 \\
\hline March & 2,4 & 4,2 & 6,1 \\
\hline April & 3,1 & 5,2 & 7,4 \\
\hline May & 3,8 & 6,4 & 9,0 \\
\hline June & 4,3 & 7,0 & 9,8 \\
\hline July & 5,0 & 8,2 & 11,3 \\
\hline August & 3,9 & 6,6 & 9,2 \\
\hline September & 3,2 & 5,5 & 7,7 \\
\hline October & 2,6 & 4,6 & 6,5 \\
\hline November & 1,5 & 3,0 & 4,4 \\
\hline December & 1,0 & 2,1 & 3,2 \\
\hline
\end{tabular}

The main unit is the electrolysis stack where the electric energy from the photovoltaic system is converted into chemical energy, producing hydrogen. Thus the little oxygen quantity in the hydrogen flow, because of the cross-over phenomenon is eliminated by catalytic combustion giving water as an output, which is subsequently eliminated by dehumidification.

There are conventional alkaline electrolyzers and advanced polymer membrane electrolyzers, which have an higher performance but are more expensive. With a $3.5 \mathrm{~kW}$ photovoltaic power system, it is enough to have a $3 \mathrm{~kW}$ power electrolyzer to be sure to utilize all solar energy to produce hydrogen, because these electrolyzers can work above the power value they are designed for.

The available energy to produce hydrogen, taking $5 \mathrm{kWh}$ from the values in Table 2 (directly used from PV), for each month and for each PV surface is shown in Table 4. So it is easy to evaluate the hydrogen quantity that the system can generate. The results are

Table 6 Chemical hydrogen energy accumulated [kWh]

\begin{tabular}{|c|c|c|c|}
\hline & \multicolumn{3}{|c|}{$E_{c}[\mathrm{kWh}]$} \\
\hline PV surface & $20 \mathrm{~m}^{2}$ & $30 \mathrm{~m}^{2}$ & $40 \mathrm{~m}^{2}$ \\
\hline January & 3,7 & 7,4 & 11 \\
\hline February & 5,1 & 9,7 & 14,2 \\
\hline March & 7,1 & 12,6 & 18,1 \\
\hline April & 9,2 & 15,7 & 22,3 \\
\hline May & 11,5 & 19,2 & 26,9 \\
\hline June & 12,8 & 21,1 & 29,4 \\
\hline July & 15,0 & 24,4 & 33,9 \\
\hline August & 11,8 & 19,7 & 27,6 \\
\hline September & 9,6 & 16,3 & 23,1 \\
\hline October & 7,9 & 13,7 & 19,5 \\
\hline November & 4,6 & 8,9 & 13,1 \\
\hline December & 2,9 & 6,3 & 9,7 \\
\hline
\end{tabular}

Table 7 Energy produced by fuel cells using stored $\mathrm{H}_{2}$ [kWh]

\begin{tabular}{|c|c|c|c|}
\hline & \multicolumn{3}{|c|}{ Produced energy $E_{p}[\mathrm{kWh}]$} \\
\hline PV surface & $20 \mathrm{~m}^{2}$ & $30 \mathrm{~m}^{2}$ & $40 \mathrm{~m}^{2}$ \\
\hline January & 1,7 & 3,5 & 5,1 \\
\hline February & 2,4 & 4,5 & 6,7 \\
\hline March & 3,3 & 5,9 & 8,5 \\
\hline April & 4,3 & 7,4 & 10,5 \\
\hline May & 5,4 & 9,0 & 12,7 \\
\hline June & 6,0 & 9,9 & 13,8 \\
\hline July & 7,1 & 11,5 & 15,9 \\
\hline August & 5,6 & 9,3 & 12,9 \\
\hline September & 4,5 & 7,7 & 10,9 \\
\hline October & 3,7 & 6,4 & 9,2 \\
\hline November & 2,2 & 4,2 & 6,1 \\
\hline December & 1,4 & 3,0 & 4,6 \\
\hline
\end{tabular}

reported in Table 5. Now the hydrogen has to be stored and, as said before, the two main options are a conventional cylindrical tank or a special one inside which a particular material adsorbs and desorbs hydrogen.

There are several kinds of materials capable of receiving and releasing hydrogen because of their own crystalline structures, which host the hydrogen atoms. In Fig. 13, the behavior of particular materials working at low temperature is reported.

Starting from a hydrogen storage pressure of 10 bar, almost all accumulated hydrogen $(90 \%)$ can be released when the pressure reaches 2-3 bar, which is the working pressure of our fuel cell system. This means that the electrolyzer has to work near 10 bar pressure to guarantee good functioning, charging the metal hydride [7].

Table 8 Available energy by photovoltaic and wind system [kWh]

\begin{tabular}{|c|c|c|c|c|}
\hline \multirow{2}{*}{} & \multicolumn{3}{|c|}{ Available Energy [kWh] } \\
\cline { 2 - 5 } & $\begin{array}{c}\text { By } 20 \mathrm{~m}^{2} \\
\text { PV } \\
\text { surface }\end{array}$ & $\begin{array}{c}\text { From } \\
\text { wind }\end{array}$ & $\begin{array}{c}\text { Used } \\
\text { directly }\end{array}$ & $\begin{array}{c}\text { Available } \\
\text { Energy to } \\
\text { produce } \\
\text { hydrogen }\end{array}$ \\
\hline January & 9,7 & +9 & -5 & $=13,7$ \\
\hline February & 11,6 & +9 & -5 & $=15,6$ \\
\hline March & 14,1 & +9 & -5 & $=18,1$ \\
\hline April & 16,8 & +9 & -5 & $=20,8$ \\
\hline May & 19,8 & +9 & -5 & $=23,8$ \\
\hline June & 21,4 & +9 & -5 & $=25,4$ \\
\hline July & 24,3 & +9 & -5 & $=28,3$ \\
\hline August & 20,2 & +9 & -5 & $=24,2$ \\
\hline September & 17,3 & +9 & -5 & $=21,3$ \\
\hline October & 15,1 & +9 & -5 & $=19,1$ \\
\hline November & 10,9 & +9 & -5 & $=14,9$ \\
\hline December & 8,7 & +9 & -5 & $=12,7$ \\
\hline
\end{tabular}




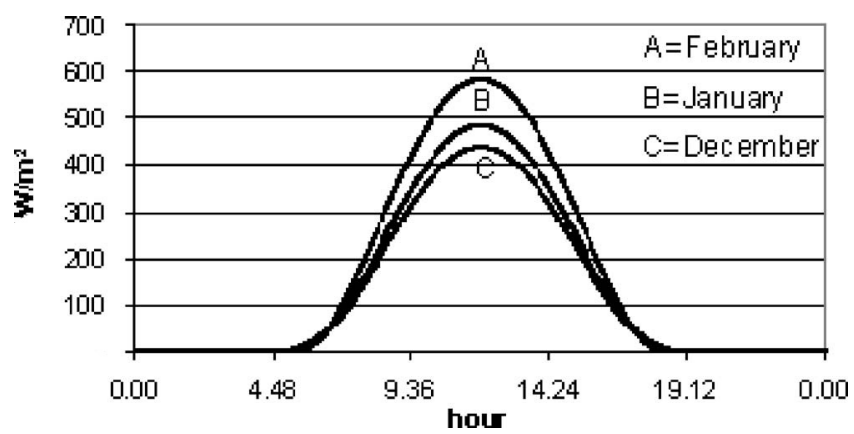

Fig. 3 Winter, $1 \mathrm{~m}^{2}$ solar panel

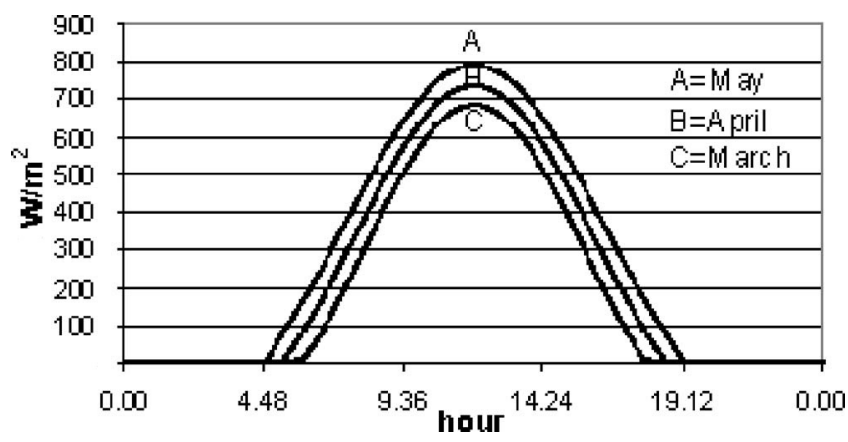

Fig. 4 Spring, $1 \mathrm{~m}^{2}$ solar panel

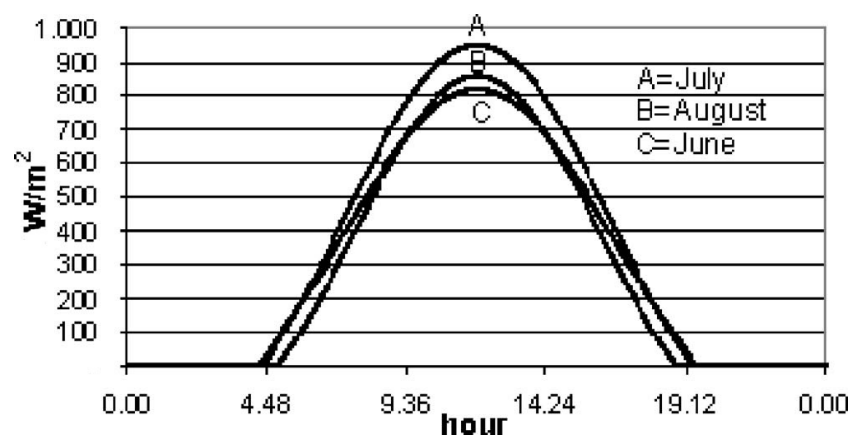

Fig. 5 Summer, $1 \mathrm{~m}^{2}$ solar panel

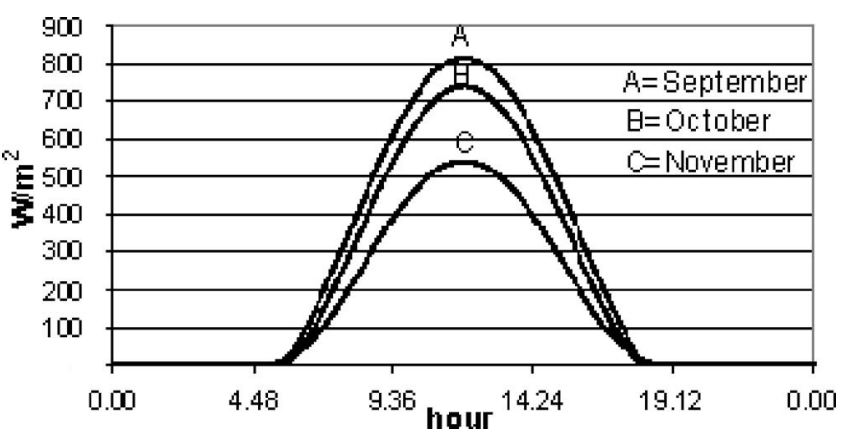

Fig. 6 Autumn, $1 \mathrm{~m}^{2}$ solar panel

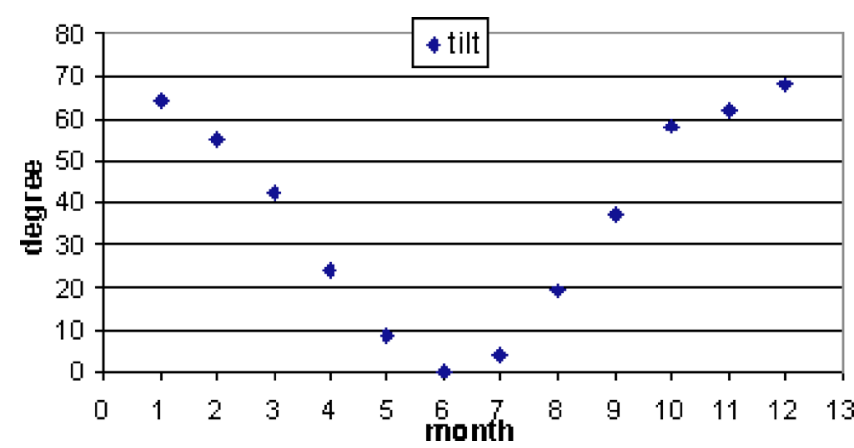

Fig. 7 Tilt value of each month of the year

The hydrogen weight percentage in metal hydrides is about $1.5 \%$. With a photovoltaic surface of $40 \mathrm{~m}^{2}$, a certain metal hydride quantity is requested to also store all hydrogen generated in July (maximum value) and it has been calculated as follows:

$$
Q=\frac{P V}{\mathrm{R} T} P M \frac{100}{1.5}
$$

where:

$P=$ pressure in "normal conditions" [atm]

$T=$ temperature in "normal conditions" $[\mathrm{K}]$

$V=$ calculated volume expressed [1]

$\mathrm{R}$ is the constant gas $(0.0821[1 \mathrm{~atm} / \mathrm{K} \mathrm{mol}]), P M$ is hydrogen molecular weight.

Thus,

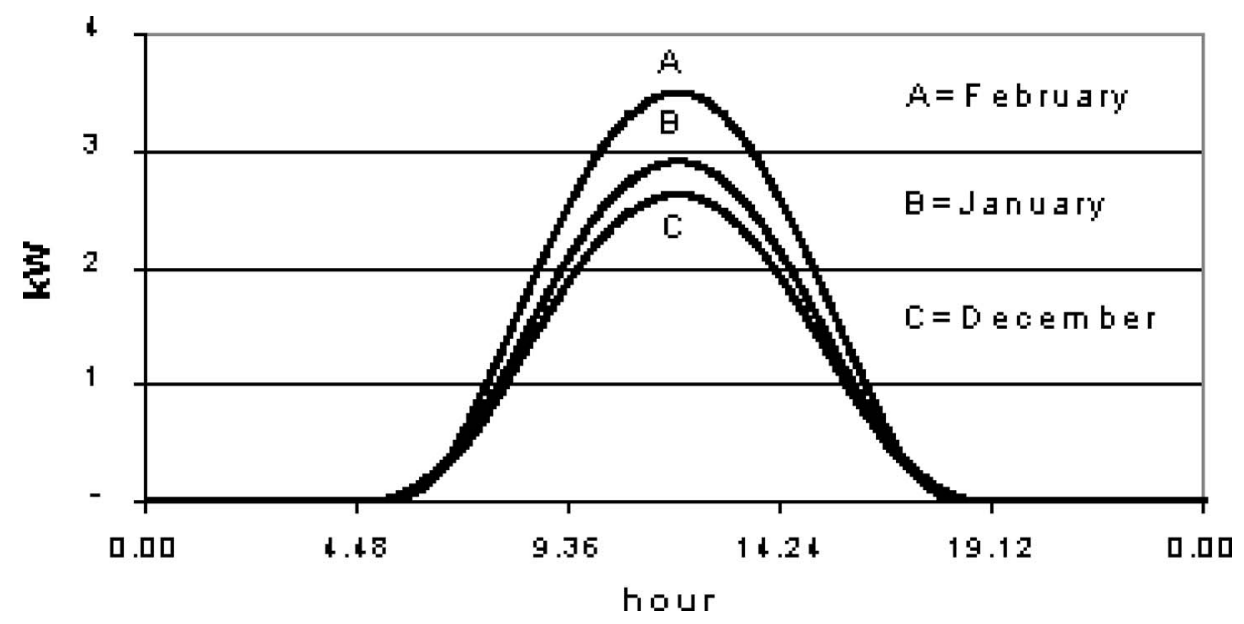

Fig. 8 Winter, $40 \mathrm{~m}^{2}$ solar panel 


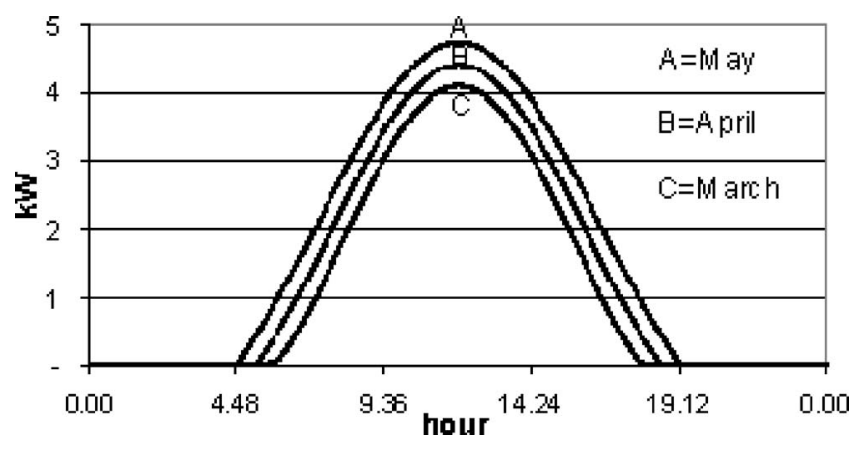

Fig. 9 Spring, $40 \mathrm{~m}^{2}$ solar panel

$$
Q=\frac{1 \times 11300}{0.0821 \times 273.15} \times 2 \times \frac{100}{1.5} \frac{1}{1000} \cong 67 \mathrm{~kg}
$$

On the market there are tanks capable of containing hydrogen up to 700 bar. Therefore, instead of using the metal hydrides, a conventional hydrogen tank working at only 10 bar can also be utilized; that is the working pressure of the electrolyzer. This solution is cheaper, but less safe. Anyhow to have hydrogen at $10 \mathrm{bar}$, that is, in absolute, a low pressure, and a technological and a safety problem does not arise.

Now the tank volume we need can be calculated and working at room temperature, the volume will be

$$
V^{I}=\frac{P V T^{I}}{T P^{I}}
$$

where

$P=$ pressure in "normal conditions" [atm]

$T=$ temperature in "normal conditions" $[\mathrm{K}]$

$V=$ calculated volume expressed [1]

$P^{I}=$ pressure in operating conditions $[\mathrm{atm}]$

$T^{I}=$ temperature in operating conditions $[\mathrm{K}]$

$$
V^{I}=\frac{1 \times 11300 \times 298.15}{273.15 \times 10} \frac{1}{1000}=1.23 \mathrm{~m}^{3}
$$

But in this case, because the fuel cell system works at $2-3$ bar, only $70-80 \%$ of the stored hydrogen can be exploited, whereas by the first method (metal hydride) up to $90 \%$ of accumulated hydrogen can be used.

Thus, in the first case, $67 / 0.9 \cong 74.5 \mathrm{~kg}$ of metal hydrides and in the second case, a normal tank of $1.23 / 0.7=1.75 \mathrm{~m}^{3}$ is needed. In both cases, the tanks have to be completely filled in.

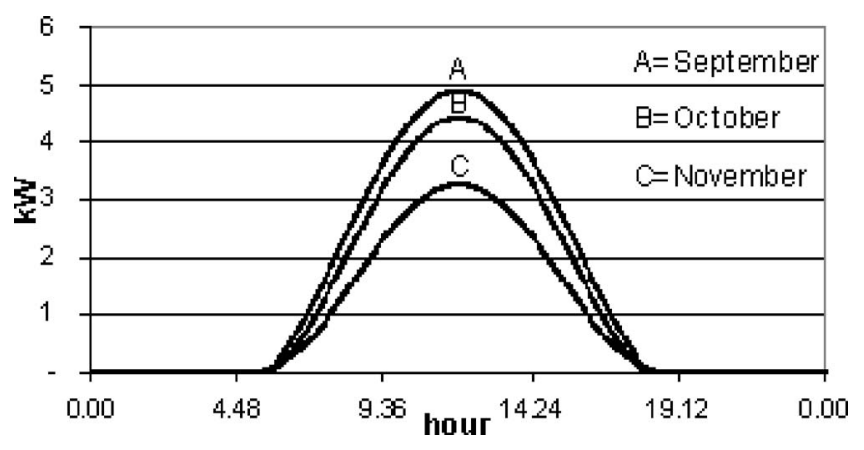

Fig. 11 Autumn, $40 \mathrm{~m}^{2}$ solar panel

Now the chemical energy contained in the accumulated hydrogen has been calculated:

$$
E_{c}=\mathrm{PCI} \times \rho V
$$

where:

LHV

low

heating

value $=120[\mathrm{MJ} / \mathrm{kg}] ; 33.33[\mathrm{kWh} / \mathrm{kg}]$

$\rho=$ hydrogen density $0.0899 \mathrm{~kg} / \mathrm{Nm}^{3}$

$V=$ calculated volume $\left[\mathrm{Nm}^{3}\right]$

When needed, this hydrogen can be utilized to produce energy by a fuel cell (FC) system that works at low temperature and has an efficiency of about 0.47 . This kind of fuel cell uses a polymer membrane technology and works with a hydrogen degree purity of $99.99 \%$, which the mentioned electrolyzer can assure.

In the end, the $4 \mathrm{kWh}$ available for the dark hours can be obtained,

$$
E_{p}=E_{c} \eta
$$

where $E_{c}$ is the chemical hydrogen energy accumulated [kWh] and $\eta$ is the fuel cell efficiency.

As shown in Table 7, only by $40 \mathrm{~m}^{2}$ of photovoltaic surface the total energy needs coverage of a family is fully accomplished, in the $30 \mathrm{~m}^{2}$ case a near value is reached, whereas in the $20 \mathrm{~m}^{2}$ one it is not. Furthermore, in parallel, energy can also be produced from the wind through an aerogenerator (Fig. 14).

In fact, if some area is characterized by about 1700 equivalent hours of wind energy during a year, then a $2 \mathrm{~kW}$ aerogenerator can produce $3400 \mathrm{kWh}$ per year and about $9.3 \mathrm{kWh}$ of average energy per day. From Table 8 it arises that the lowest value of

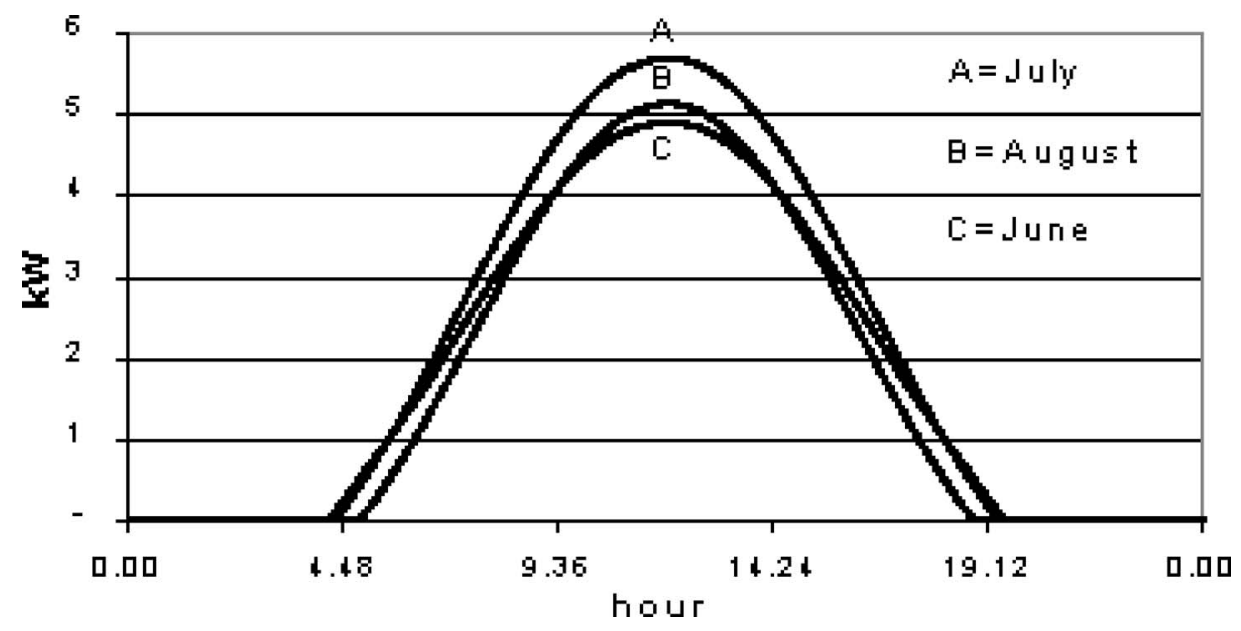

Fig. 10 Summer, $40 \mathrm{~m}^{2}$ solar panel 


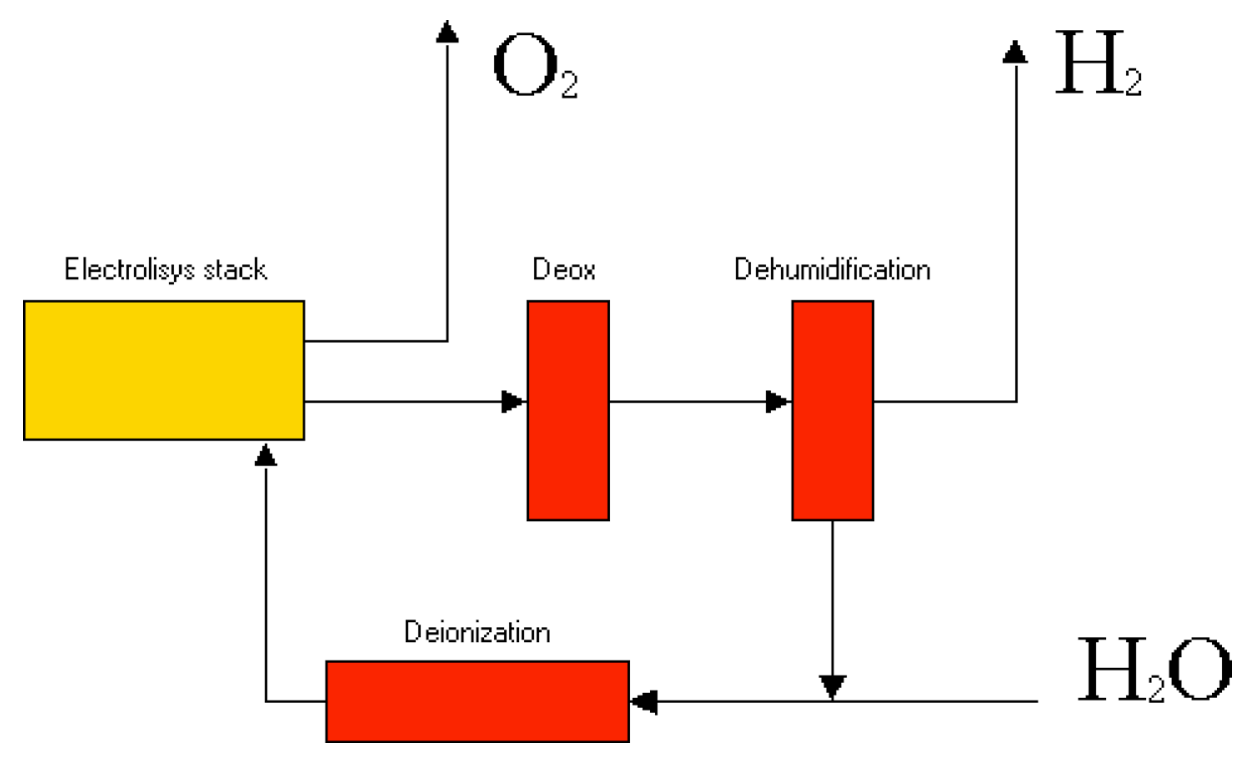

Fig. 12 Electrolysis

Discharging ourves for Low Temperature Hydrides at $T=25^{\circ} \mathrm{C}$

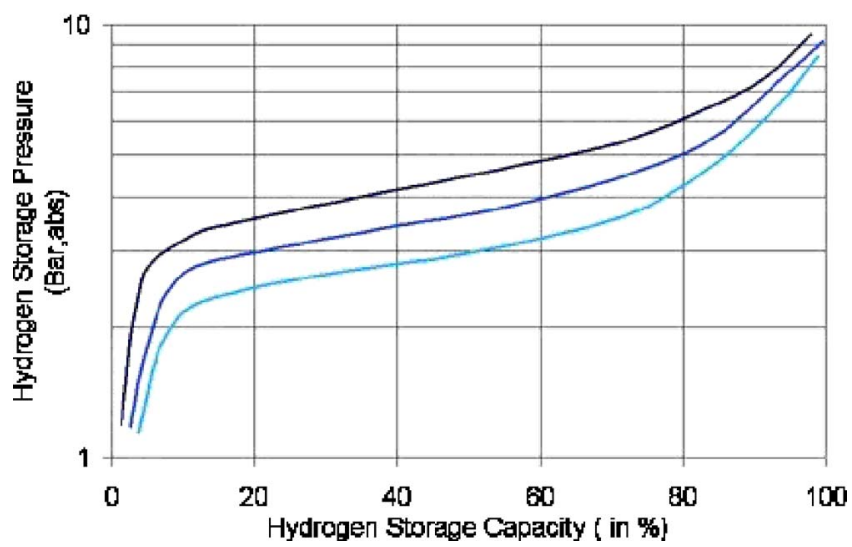

Fig. 13 Discharging curves for low temperature hydrades at $T=25^{\circ} \mathrm{C}$

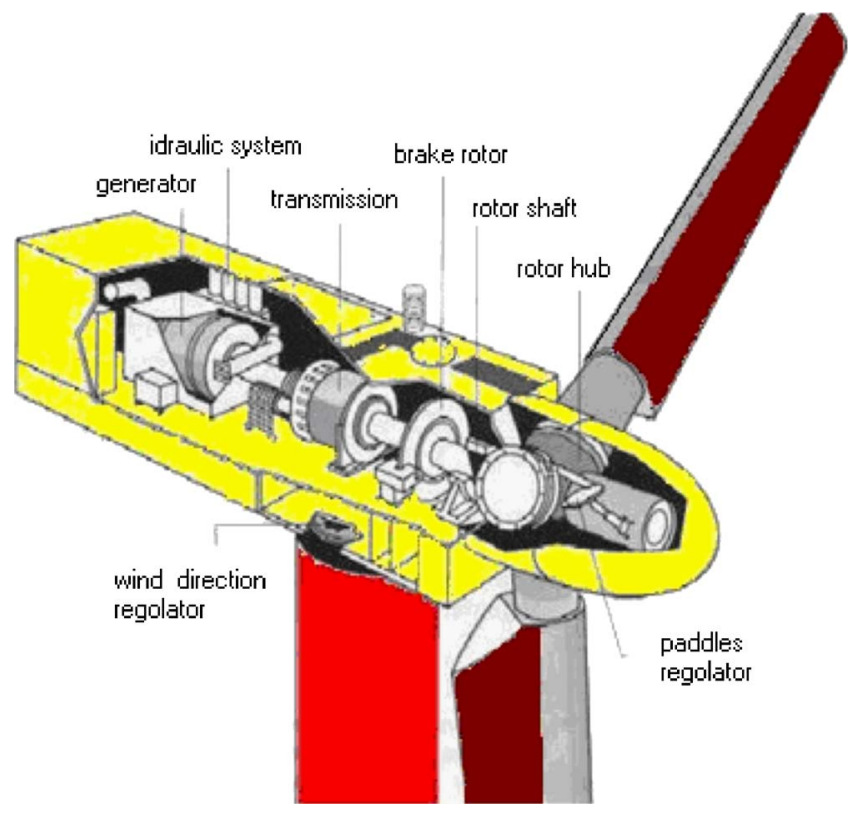

Fig. 14 Aerogenerator available energy to produce hydrogen is located in December $(12.7 \mathrm{kWh})$, and this value is close to that reported in Table 4 $\left(40 \mathrm{~m}^{2}\right)$, even in December $(12.5 \mathrm{kWh})$. Hence, the necessary energy for the users is supplied in that case as well.

The first necessary step to be undertaken is to test the place with an anemometer for one year to verify the yearly average wind speed. A power control unit has to manage the system so it will understand the user's priorities. In other words, only the surplus energy has to be used to produce hydrogen; otherwise, it would be energetically inefficient to get energy from hydrogen instead of directly produce it from the primary source (photovoltaic, wind).

A scheme of the system is depicted in Fig. 15. When the energy is derived from the wind system, a converter (chopper) to stabilize the input electrolyzer voltage coming from photovoltaic panels, an inverter to provide an alternate current load directly from photovoltaic system or from a fuel cell system, and a rectifier that provides direct current to the electrolyzer are also foreseen. Moreover a UCS (unit control system) has to control the entire the system. If the system is producing hydrogen and the user needs more energy the UCS stops the hydrogen production and starts up the primary power source (photovoltaic or wind system or both).

\section{Conclusions}

Everywhere energy supply systems can be successfully designed, built, and diffused by using available technologies for a

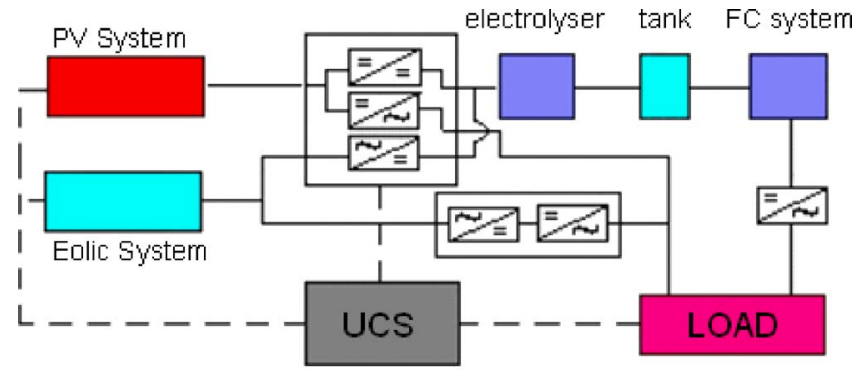

converter

inverter

rectifier

Fig. 15 Integrated system scheme 
very large number of utilizations. The potential of this kind of innovative integrated system increases when it is possible to profit, as a primary energy source, from both direct insulation and wind flow, to be exploited together with small-scale aerogenerators. The unit control system of the proposed modular power generator allows one to manage different kinds of energy inputs, such as PV and wind. Furthermore, in this system the possibility of integrating mini and micro hydro power plants (when possible) is also foreseen.

The integration, optimization, and industrialization of the system, as a $3.5 \mathrm{~kW}_{\mathrm{p}}$ electricity "zero-emissions-zeroconsumption" generator, is proved. The proposed system shows that it is possible to self-produce its one's own renewable fuel, guaranteeing a clean electricity supply for an average family's home energy needs in Rome, Italy. This system is composed of a polymer membrane electrolyzer, a metal hydride hydrogen storage (which absorbs and desorbs hydrogen), and a polymer fuel cell (PEM).

The system modularity guarantees the possibility to satisfy larger energy needs, and the metal hydrides low-pressure hydrogen storage ensures a home appliance level of safety.

Future developments of this research will be finalized with a market analysis for evaluating real market opportunities of the "everywhere energy supply" system with its current configuration. On the other side, the technological evolution particularly refer- ring to the additional heating capability of fuel cells for heat and cold production will be investigated, aiming at increasing overall energy efficiency.

\section{Acknowledgment}

The authors wish to thank their scientific mentor Professor Vincenzo Naso, director of CIRPS. The industrialization and marketing of the "everywhere energy supply" system are being carried out within a spin-off project financed by FILAS-Finanziaria Laziale di Sviluppo S.p.A.-Regione Lazio.

\section{References}

[1] Orecchini, F., Santiangeli, A., and Naso, V., 2003, Renewable Hydrogen Proceedings Hypothesis $V$, Porto Conte Ricerche, Alghero, Italy.

[2] Orecchini, F., and Naso, V., 2003, La Società No Oil, Orme Editori, Milano.

[3] Lazzarin, R., 1981, Sistemi Solari Attivi: Manuale Di Calcolo (Solar Passive Systems: A Calculation Handbook), F. Muzzio and C. Padova, ed., Padova.

[4] Collares-Pereira, M., and Rabl, A., 1979, "The Average Distribution of Solar Radiation: Correlations Between Diffuse and Hemispherical and Between Daily and Hourly Insolation Values," Sol. Energy, 22, pp. 155-164.

[5] Hopkinson, R. G., Petherbridge, P., and Longmore, J., 1963, Daylighting, Heinemann, London.

[6] Cucumo, M., Kaliakatzos, D., Marinelli, V., and Vivacqua, M. D., 1997, "Metodi di Calcolo Della Luminanza Del Cielo e Dell'Illuminamento Naturale su Superfici Esterne," ("Calculation Methods of Sky Luminance and Daylighting of External Surfaces”) CDA, 5, pp. 485-496.

[7] Krishna, Sapru, Ramachandran, S., and Tan, Z., 2000, "An Integrated PVElectrolysis Metal Hydride Hydrogen Generation and Storage System," Proceedings of the 2000 Hydrogen Program Review, NREL, San Ramon, California, pp. $155-162$. 